\title{
PENERAPAN MANAJEMEN MUTU PADA BAGIAN PRODUKSI TEPUNG DAUN KELOR CV NURUL JANNAH KABUPATEN SUMENEP
}

\author{
Moh. Salantoni ${ }^{1 *}$, Ida Ekawati $^{2}$, Isdiantoni ${ }^{3}$ \\ Prodi Agribisnis Fakultas Pertanian Universitas Wiraraja \\ Jl. Raya Sumenep-Pamekasan KM-05 Patean, Sumenep, Jawa Timur 69451 \\ salantoni2002@gmail.com
}

\begin{abstract}
ABSTRAK
CV. Nurul Jannah adalah perusahaan kecil menengah dengan jenis produk yang menjadi komoditas utama adalah tepung daun kelor. Penelitian dilakukan untuk mengetahui permasalahan dalam penerapan mutu serta menentukan alternatif strategi sebagai pemecahan masalah dalam penerapan manajemen mutu terpadu. Pengumpulan data dilakukan dengan wawancara dan observasi. Metode analisis menggunakan pareto diagram dan analytical hierarki process (AHP). Hasil penelitian menunjukan masalah utama dalam penerapan manajemen mutu secara berturut-turut sesuai tingkat kepentingan adalah pemenuhan persyaratan ijin BPOM $(52,9 \%)$, kualitas bahan baku yang kurang baik $(23,8 \%)$, dan jumlah pasokan bahan baku yang tidak menentu (13,2\%). Akar masalah terhadap kepentingan pemenuhan persyaratan ijin BPOM adalah keamanan pangan $(0,67)$. Kemudian untuk akar masalah dari kualitas bahan baku adalah kualitas bahan baku yang tidak sesuai SOP $(0,58)$. Untuk akar masalah pasokan bahan baku yang tidak kontinu adalah kuantitas bahan baku (0, 68). Hasil analisa menunjukkan alternatif perbaikan berturut-turut yang diprioritaskan yaitu: perbaikan sistem manajemen mutu $(0,65)$, kemitraan kerja $(0,23)$, dan peningkatan kinerja $\operatorname{SDM}(0,12)$.
\end{abstract}

Kata kunci: Alternatif, manajemen mutu, penyelesaian, permasalahan

\begin{abstract}
$C V$. Nurul Jannah is a small and medium company with the type of product that is the main commodity is moringa leaf flour. This study the main problems of CV Nurul Jannah to implementing quality management as well as alternative strategies that can be offered to overcome problems in implementing integrated quality management. Analysis data used pareti diagram and analytical hierarki process. The main problems in implementing quality management in a row according to the level of importance are the fulfillment of BPOM permit requirements (52.9\%), poor raw material quality (23.8\%), and an uncertain amount of raw material supply (13.2\%). The root of the problem with regard to the importance of fulfilling BPOM permit requirements is food safety (0.67). Then for the root problem of the quality of raw materials is the quality of raw materials that are not in accordance with SOP $(0,58)$. For the root of the problem of non-continuous supply of raw materials is the quantity of raw materials $(0,68)$. The alternative priorities for improvement are adjusted to the company's condition in sequence, namely improving the quality management system (0.65), working partnerships (0.23), and improving HR performance (0.12).
\end{abstract}

Keywords: Alternative, quality management, problems 


\section{PENDAHULUAN}

Tanaman kelor dikenal sebagai tanaman kaya akan nutrisi di dunia dan WHO memperkenalkannnya sebagai tanaman untuk mengatasi masalah gizi (malnutrisi). Broin (dalam Aminah, 2015). Badan pengawasan bahan obat dan makanan mengelompokkan kelor sebagai tanaman obat, sebab kandungan dan manfaat kelor yang fantastis. Di asia dan afrika tanaman kelor diolah menjadi suplemen yang memiliki kandungan gizi yang melimpah bagi ibu menyusui maupun pada masa pertumbuhan anak. Semua bagian dapat menjadi bahan baku industri karena mengandung gizi tinggi serta memiliki manfaat kesehatan.

Di Kabupaten Sumenep terdapat sebuah industri yang bergerak di bidang pengolahan daun kelor yaitu C.V. Nurul Jannah. Industri tersebut memiliki banyak produk olahan yang berbahan baku daun kelor salah satuhnya tepung kelor dan kapsul kelor. Produk tersebut dipasarkan di pasar lokal dan internasional. Untuk menjaga keamanan dan kesehatan produknya C..V Nurul Jannah harus memenuhi kriteria-kriterian yang di muat dalam Undang-Undang, diantaranya UU NO 8 tahun 1999 mengenai perlindungan terhadap konsumen dan UU NO 18 tahun 2012 tentang pangan

Salah satu Undang-Undang yang harus dipatuhi adalah UU NO 8 tahun 1999 mengenai perlindungan terhadap konsumen. Undang-Undang tersebut berfungsi untuk meningkatkan sebuah kualitas hidup konsumen seperti keamanan, kesehatan, dan keselamatan konsumen sehingga para produsen dengan otomatis meningkatkan mutu dari produk yang akan merek produksi. Dalam Undang-Undang ini juga disebutkan bahwa konsumen berhak dalam memperoleh sebuah kegunaan suatu produk (barang/jasa) yang memiliki nilai sama dengan pengorbanan yang dikeluarkan oleh konsumen. Konsumen juga behak mendapatkan jaminan mutu yang diberikan atas sebuah barang, kenyamanan, serta keamanan dan kesehatan suatu produk.

Untuk mendukung Undang-Undang perlindungan konsumen maka pemerintah membentuk UU NO 18 tahun 2012 tentang pangan, dimana dalam Undang-Undang tersebut dipaparkan pangan merupakan segalah sumber yang dihasilkan oleh sumber hayati maupun air. Dimana sumber-sumber tersebut sudah diolah mauoun tidak diolah yang akan dijadikan makanan atau minuman yang akan digunakan oleh manusia dalam kehidupan sehari-hari, ataupun sebagai bahan baku untuk pembuatan produk baru (makanan dan minuman) harus aman jika dikonsumsi oleh konsumen (manusia).

Dalam menghasilkan produk yang baik dan aman sesusai dengan pernyataan di atas, maka C.V. Nurul Jannah diharuskan menerapkan suatau standart mutu dalam melakukan kegiatan produksi. Sebab kegiatan produksi merupakan kegiatan penting bagi C.V. Nurul Jannah untuk mengasilkan sebuah produk yang berkualitas. Dengan diterapkannya manajemen mutu yang baik pada industri tersebut, maka industri tersebut dapat menghasilkan produk-produk yang memiliki kualitas tinggi. Sehingga nantinya akan didapat sebuah keuntungan yang maksimal dan mampu menjaga siklus kehidupan industri tersubut (Nasution, 2004).

Dengan uraian diatas maka peneliti merumuskan permasalahan bagaimanakah penerapan manajemen mutu dibagian produksi di CV. Nurul Jannah dan masalah apa yang timbul serta alternatif penyelesaian apa yang harus dilakukan.

\section{METODE PENELITIAN}

Model analisis dalam penelitian mengenai penerapan manajemen mutu pada bagian produksi tepung daun kelor $\mathrm{CV}$. Nurul Jannah. Metode analisis menggunakan diagram pareto dan analikal hirarki proses.

Data primer yang digunakan merupakan yang bersifat kualitatif diantaranya desain produk, pelaksanaan standar prosedur 
operasional, pengendalian bahan baku, pengendalian mutu produk pada proses produksi dan pengendalian mutu pada produk akhir. Data primer didapatkan oleh peneliti secara langsung melalui wawancara dan observasi lapangan. Selain data primer, sebagai data pendukung juga digunakan data sekunder.

Tahapan yang dilakukan dalam pengolahan data adalah (1) menganalisa penerapan manajemen mutu di bagian produksi pada CV. Nurul jannah menggunakan analisa diskriptif, (2) akurasi yang dilakukan melalui pemeriksaan secara langsung melalui observasi untuk menyesuaikan dengan data yang telah diperoleh dari kegiatan wawancara, (3) input data mengenai penerapan manajemen mutu dibagian produksi dan permasalahan yang dialami oleh pihak perusahaan kedalam alat analisa minitab 2015, kemudian dianalisa menggunakan analitikal hirarki proses untuk mengetahui akar penyebab masalah dengan bantuan menggunakan microsoft excel.

\section{HASIL DAN PEMBAHASAN}

\section{A. Desain Produk Sebagai Orientasi Kepuasan Konsumen}

Pihak perusahan dalam menentukan desain produk mempertimbangkan sebuah masukan atau permintaan konsumen. Desain produk tepung daun kelor yang dibuat oleh pihak perusahaan harus mengacu pada beberapa kriteria yang telah ditentukan oleh konsumen. Berdasarkan informasi yang didapatkan dari pihak manajemen CV. Nurul Jannah, yaitu bapak Moh. Waris Romadhani menjelaskan beberapa kriteria yang diharapkan oleh konsumen mengenai produk tepung daun kelor:

1. Tepung kelor organik, merupakan tepung daun kelor yang dihasilkan dari bahan daun kelor dengan sistem budidaya yang tanpa menggunakan bahan kimia seperti pestisida, pupuk anorganik dan bahan semacamnya (Pracaya dalam Gribaldi, 2009)
2. Ukuran partikel, tepung yang diproduksi minimal 200 mesh sebab tepung kelor tersebut dijadikan bahan tambahan pembuatan pangan lain (SNI 01-3751-2006)

3. Warna, tepung kelor harus memiliki warna yang hijau natural atau hijau daun kelor sebab daun tepung daun kelor yang berwarna hijau menunjukkan bahwa daun yang digunakan dalam proses produksi masih segar dan memiliki kualitas baik.

4. Legalitas produk (BPOM), tepung daun kelor yang dihasilkan harus memenuhi standar BPOM dengan indikator higeinitas, keamanan dan mutu baik yang didasarkan atas Undang-Undang No 8 Tahun 1999 pasal 4 ayat A temtamg perlindungan konsumen

Berdasarkan Undang-Undang No 8 Tahun 1999 pasal 4 ayat A tentang perlindungan konsumen diatas, pangan yang dimaksud higeinis, aman dan bermutu serta kemasan yang tidak berbahaya adalah sebagai berikut:

1. Higienis, berdasarkan UU No 7 tahun 1996 pasaal 4-6 tentang pangan menjelaskan bahwa pangan bebas dari kotoran dan memenuhi standar gizi serta tidak terkontaminasi oleh oleh mikroba (bakteri, virus, jamur, dll) yang mampu membahayakan bagi tubuh manusia.

2. Keamanan, berdasarkan UU No 7 Tahun 1996 pasal 21 tentang pangan menerangkan bahwa bahan pangan tidak boleh mengandung bahan beracun, berbahaya, atau dapat merugikan atau membahayakan kesehatan atau jiwa manusia, walaupun terdapat cemaran tidak boleh melebihi batas toleransi yng ditetapkan.

3. Mutu pangan, berdasarkan UU No 7 Tahun 1996 pasal 25 dan 26 tentang pangan mengartikan pangan harus 
memenuhi Standar Nasional Indonesia (SNI) dan memiliki sertifikasi dari SNI 7387:2009 untuk memastikan bahwa pangan memiliki mutu yang baik

4. Kemasan, berdasarkan UU No 7 Tahun 1996 pasal 16 tentang pangan kemasan yang digunakan harus mampu melindungi pangan dari kerusakan atau pencemaran pada produk pangan dan bukan merupakan bahan yang dilarang oleh pemerintah.

Berikut hasil perbandingan produk yang dihasilkan oleh pihak CV. Nurul Jannah dengan kriteria yang diharapkan oleh konsumen dapat dilihat pada tabel 1 .

Tabel 1. kriteria tepung daun kelor yang diharapkan konsumen




natural, kemudian bertugas untuk melakukan penimbangan pada daun.

Bahan baku yang digunakan merupakan daun kelor yang didapatkan dari kelompok tani binaan CV. Nurul Jannah yang berjumlah 40 kelompok tani dengan kepemilikan pohon rata-rata 1000 pohon dengan harga Rp. 2.000/kg. Dengan kriteria kelor organik dan berwarna hijau. Namun pada penerapannya, kelor yang didapat masih merupakan bahan yang berasal dari budi daya semi organik sebab tanaman kelor yang di budidayakan oleh kelompok tani menggunakan pupuk organik, namun tanaman kelor ditanam di pinggiran lahan sawah yang ditanami tanaman seperti jagung dan padi yang menggunakan pupuk anorganik.

\section{b. Pencucian daun}

Pada bagian ini karyawan bertugas untuk membersihkan daun dengan air bersih. Pencucian dimulai dengan mengikat beberapa tangkai daun kemudian dicelupkan pada bak pencucian sebanyak tiga tahap (tiga bak) menggunakan air yang dialirkan oleh PDAM. Pada bak 1 air harus diganti setelah lima (5) kali pencucian, bak 2 dilakukan pergantian air setelah 20 kali bilasan, dan pada bak 3 tidak dilakukan pergantian sama sekali selama satu kali proses produksi atau satu hari. Kemudian daun ditiriskan selama 15 menit dan ditimbang sebanyak $15 \mathrm{~kg}$ dan dimasukkan kedalam keranjang untuk masuk ke tahap selanjutnya. Karyawan yang memegang tanggung jawab ini melaksanakan tugasnya dengan cukup baik walau terkadang karyawan mengganti air pada bak ke 2 yang seharusnya dilakukan setelah 20 kali pencucian, namun karyawan melakukan pergantiang setelah 22-23 kali pencucian dengan alasan air masih jernih.

\section{c. Pemisahan helai daun}

Pada bagian ini karyawan bertugas untuk melepaskan daun kelor yang menempel pada tangkai daun. Pemisahan ini dilakukan untuk sortasi daun dengan melepaskannya dari tangkai sekunder dan hanya batang tersier (batang yang menempel pada daun) yang boleh ikut diproduksi atau digiling dan juga daun akan dipisahkan berdasarkan kualitas warna daun antara daun kuning dan daun yang masih berwarna hijau segar Pada tahap ini karyawan diwajibkan menggunakan masker, sarung tangan dan penutup kepala.

Waktu pimisahan helai daun dari tangkai harus dilakukan secepat mungkin sebab untuk menghasilkan warna tepung yang hijau segar harus diproses maksimal tujuh jam (7 jam) setelah bahan baku didapatkan. berdasarkan hasil wawancara dengan pihak manajemen perusahaan waktu yang dibutuhkan rata-rata oleh perusahaan selama 6 jam.

\section{d. Pengeringan daun}

Daun yang telah disortir kemudian dimasukkan dalam oven ruangan untuk menurunkan kadar air daun kelor hingga 9\% yang diukur menggunakan alat pengukur kadar air (moisture meter). Pengeringan sesuai standart dilakukan selama 16 jam pada suhu $40-45^{\circ} \mathrm{C}$.

Pada CV. Nurul Jannah bagian ini karyawan bertugas untuk menyusun daun pada rak yang berukuran $60 \mathrm{~cm} \times 110 \mathrm{~cm}$ yang terdapat di ruangan pengering pada suhu $40-45^{\circ} \mathrm{C}$ selama 16 jam yang dimulai dari jam 16.00 WIB dan dilakukan pengecekan suhu selama 5 jam sekali, karyawan yang bertugas untuk mengecek suhu adalah karyawan yang memiliki tugas untuk menjaga keamanan pebrik di malam hari. Daun kelor ditata dengan ketebalan kelor pada rak setebal $3 \mathrm{~cm}$. Kemudian setelah itu daun diambil dan dimasukkan kedalam plastik. Pada tahap ini karyawan diwajibkan menggunakan masker, sarung tangan dan penutup kepala. Hal ini menunjukkan perusahaan telah memenuhi SOP pada bagian ini.

\section{e. Proses Powdering}

Pada bagian ini karyawan ditugaskan untuk menghaluskan daun yang telah dikeringkan. Proses penghalusan terdiri dari dua tahap yaitu tahap pertama dilakukan penggilingan dengan ukuran partikel 60 
mesh. Pada tahap penggilingan ke dua tepung dengan ukuran 60 mesh digiling kembali dengan menggunakan mesin penggiling dengan sistem vakum sehingga tepung yang dihasilkan mempunyai ukuran partikel 300 mesh. Kemudian tepung dengan ukuran 300 meh tersebut dimasukkan ke dalam oven lemari pada suhu $70^{\circ} \mathrm{C}-80^{\circ} \mathrm{C}$ selama satu jam untuk mengurangi kadar air hingga mencapai 7,5\% dan mematikan bakteri yang masih tersisah.

\section{f. Pengepakan}

Pada bagian ini karyawan bertugas untuk melakukan pengemasan pada tepung daun kelor dengan memasukkan pada wadah alumunium foil dengan berat isi $3,5 \mathrm{~kg}$. Kemudian tepung yang sudah dikemas di sealers pada mesin continus sealers dan dimasukkan pada kardus dengan tiap kardus

Tabel 2. Pengendalian mutu bahan baku CV. Nurul Jannah

\begin{tabular}{lll}
\hline No & $\begin{array}{l}\text { Mutu bahan baku kelor menurut CV } \\
\text { Hikmah berdasarkan kriteria konsumen }\end{array}$ & CV Nurul Jannah \\
\hline 1 & Daun kelor berasal dari budidaya organik & Berasal dari budidaya semi organik \\
2 & Berwarna hijau segar & Hijau segar \\
3 & Bebas hama penyakit/kontaminan & Bebas hama penyakit \\
\hline
\end{tabular}

Tabel 2 menunjukkan pihak CV. Nurul Jannah melakukan pengendalian bahan baku di antaranya untuk mendapatkan tepung daun kelor dengan warna yang hijau segar. Pihak perusahaan membuat strategi agar daun kelor harus sudah berada di perusahaan sebelum jam 08.00 WIB agar daun tidak terkena sinar matahari. Pihak perusahaan juga memberikan arahan kepada petani agar umur panen dikisaran 40 hari setelah daun dipanen sebelumnya.

Kemudian untuk mendapatkan daun kelor yang bebas hama penyakit/kontaminan, pihak perusahaan melakukan pengarahan atau pembinaan budi daya tanaman kelor yang baik sehingga didapatkan kelor yang bebas hama dan penyakit. Pihak perusahaan juga melakukan sortasi terhadap daun yang masih cacat atupun warna daun yang menguning.

Berdasarkan hasil observasi yang dilakukan dapat diketahui bahwa pihak $\mathrm{CV}$. berisi empat (4) kemasan alumunium foil dan kemudian di strapping dengan strapping band.

Hasil observasi terhadap perusahaaan maka dapat dikatakan sistem standard operating procedure dijalankan meskipun terdapat prosedur yang masih belum terlaksana dengan baik seperti penggunaan bahan baku semi organik sedangkan di SOP dijelaskan bahan baku yang digunakan harus organik. Proses pengeringan daun juga belum menerapkan prosedur sepenuhnya yaitu menggunakan suhu tinggi $\left(70^{\circ}-80^{\circ} \mathrm{C}\right)$.

\section{Pengendaliaan Mutu Bahan Baku}

Pengendalian mutu bahan baku yang dilakukan oleh CV. Nurul Jannah mengacu pada kririteria konsumen. Berikut pengendakian mutu pada bahan baku dapat dilihat pada tabel 2 . Nurul Jannah untuk mendapatkan kelor organik masih belum tercapai pihak manajemen perusahaan menyatakan bahwa kelor yang didapatkan masih berasal dari budidaya semi organik. Selain itu pihak perusahaan juga melakukan pemberdayaan terhadap para kelompok tani yang berjumlah 40 kelompok tani agar kualitas bahan baku yang mereka dapatkan memiliki kualitas yang konsisten.

Kemudian pada kuantitas bahan bahan baku, kapasitas yang ditargetkan oleh pihak CV. Nurul Jannah sebesar $700 \mathrm{~kg}$. Dari bahan baku tersebut pada keadaan normal akan dihasilkan tepung kelor

sebanyak $150 \mathrm{~kg}$. Untuk memenuhi target tersebut maka perusahaan melakukan pembinaan terhadap 40 kelompok tani dengan kepimilikan pohon masing-masing 1000 pohon. Namun untuk kontinuitas bahan baku daun kelor, pihak perusahaan tidak melakukan perjanjian dengan MOU yang menyangkut bahwa petani harus 
menjual hasil panen pada CV. Nurul Jannah sehingga tidak jarang pasokan bahan baku melebihi atau kurang dari target, biasanya mencapai kurang lebih $50 \mathrm{~kg}$.

Pengendalian bahan baku menurut Peraturan Menteri Perindustrian Republik Indonesia Nomor 75 tahun 2010 tentang Good Manufacturing Practices (GMP) harus memenuhi beberapa kriteria yaitu:

1. Bahan yang digunakan harus sesuai dengan standar mutu.

2. Bahan yang digunakan harus lolos periksa/uji organoleptik, fisik (benda atau bahan pengotor dapat berupa kerikil, pasir dan benda lain selain bahan baku) dan kimia (bebas dari bahan kimia berbahaya).

3. Perusahaan seharusnya memiliki catatan setiap bahan yang digunakan sebagai acuan untuk perbaikan.

Jika dibandingkan dengan beberapa tahap pengendalian mutu bahan baku yang telah dilakukan oleh CV. Nurul Jannah, maka dapat dikatakan bahwa penegndalian bahan baku yang dilakukan oleh pihak perusahaan masih belum sempurna. Pihak perusahaan belum memiliki SOP mengenai bahan baku, bagaimana bahan baku itu didapatkan, seharusnya bahan baku harus mendapatkan perlakuan yang baik dimulai dari penerimaan bahan baku yang harus ditetapkan mutunya. Kemudian bahan baku di simpan di tempat yang terbebas dari pencemaran. Berikut persyaratan penyimpanan bahan baku sesuai peraturan Menteri Perindustrian No 75 Tahun 2010:

1. Bahan yang akan diproses pada pengolahan maupun produk akhir harus disimpan terpisah di dalam ruang yang bersih, aliran udara terjamin, suhu sesuai, cukup penerangan, dan bebas hama.

2. Bahan baku seharusnya disimpan dalam keadaan tidak menyentuh lantai, menempel dinding dan jauh dari langitlangit.

3. Bahan dan produk akhir yang disimpan harus diberi tanda dan ditepatkan secara terpisah sehingga dapat dibedakan antara sebelum dan sesudah diperiksa, memenuhi dan tidak memenuhi syarat serta bahan yang diproduksi sesuai dengan urutan masuknya.

4. Penyimpanan bahan seharusnya disertai catatan kartu dengan menyertakan identitas produk seperti nama produk, tanggal produksi, kode produksi, dan informasi lain yang diperlukan.

CV Nurul Jannah belum melakukan uji terhadap bahan baku sebelum di proses. Padahal hal tersebut telah disebutkan pada Peraturan Menteri Perindustrian Republik Indonesia No 75 Tahun 2010 untuk memastikan bahan baku yang digunakan aman bagi kesehatan manusia dan memenuhi persyaratan mutu. Pihak perusahaan seharusnya dalam menangani bahan baku dapat menggunakan sistem HACCP yaitu dengan menentukan titik kritis dan penentuan bahaya sehingga bahan baku aman untuk diproses.

\section{Pengendalian mutu produk dalam proses produksi}

Pengawasan terhadap pengerjaan bahan baku pada setiap tahap meliputi pengawasan terhadap peralatan dan mesin, tenaga kerja dan kebersihan dalam proses. Proses yang dimaksudkan disini yaitu dari pencucian sampai pengepakan tepung kelor. Pengendalian yang dilakukan CV Nurul Jannah sebagaimana tabel 3

Tabel 3. Pengendalian Mutu pada Proses Produksi

\begin{tabular}{|c|c|c|c|}
\hline No & $\begin{array}{l}\text { Standar proses } \\
\text { produksi }\end{array}$ & $\begin{array}{l}\text { Keterangan (sumber: } \\
\text { Association Of Ghana) }\end{array}$ & CV. Nurul Jannah \\
\hline 1 & pencucian & $\begin{array}{l}\text { Cuci menggunakan air bersih/air yang } \\
\text { bisa diminum, kemudian cuci dengan } 1 \% \\
\text { larutan garam dan dicuci kembali dengan } \\
\text { air dan ditiriskan selama } 15 \text { menit. }\end{array}$ & $\begin{array}{l}\text { Dicuci menggunakan air } \\
\text { biasa untuk menghilangkan } \\
\text { kotoran yang menempel pada } \\
\text { daun dan ditiriskan. }\end{array}$ \\
\hline 2 & $\begin{array}{ll}\text { Pemisahan } & \text { helai } \\
\text { daun dari }\end{array}$ & $\begin{array}{l}\text { Pemisahan daun dari tangkai dan } \\
\text { kemudian daun yang rusak atau sakit }\end{array}$ & $\begin{array}{l}\text { Dilakukan sorttasi terhadap } \\
\text { daun yang berwarna kuning }\end{array}$ \\
\hline
\end{tabular}




\begin{tabular}{ll}
\hline tangkai & harus dibuang \\
& Room drying, \\
dikeringkan selama maksimal 4 hari \\
dengan kepadatan $<1 \mathrm{~kg} / \mathrm{m} 2$ pada ruang \\
\\
vertilasi baik. \\
& Solar drying, sebarkan daun pada wadah \\
& yang diberi pelindung UV sekitar 4 jam \\
& dengan suhu $35^{\circ} \mathrm{C}-55^{\circ} \mathrm{C}$ \\
& Mechanical drying, pengeringan udara \\
& panas dengan suhu antara $50{ }^{\circ} \mathrm{C}-55^{\circ} \mathrm{C}$ \\
& daun dapat ditumbuk dalam mortar, atau \\
& digiling dngan blender dapur untuk Skala \\
& kecil dan untuk skala besar dapat \\
& menggunakan burr mill atau menyewa \\
& pabrik hammer komersial untuk \\
& penggilingan rutin
\end{tabular}

5 Pengayakan

6

Penge Dikemas dalam wadah yang mampu pakan menjaga kelembapan

Dilakukan jika perlu, ukuran partikal yang disarankan Kasar $(1,0 \mathrm{~mm}-1,5 \mathrm{~mm})$, Denda $(0,5 \mathrm{~mm}-1,0 \mathrm{~mm})$, Sangat halus $(0,2 \mathrm{~mm}-0,5 \mathrm{~mm})$

Penger Bubuk daun kelor yang memiliki sifat ingan higroskopis, maka tepung kelor harus dikeringkan dengan suhu $50^{\circ} \mathrm{C}$ selama 30 menit untuk mengurangi kadar air hingga berada di bawah $7,5 \%$. dan hijau segar dan daun-

daun yang cacat

Dikeringkan menggunakan oven ruangan dengan suhu $40-45^{\circ} \mathrm{C}$ yang disususn pada rak papan selama 16 jam dengan hingga kadar air 9\%

Penggilingan dilakukan 2 kali yaitu digiling menggunakan mesin dismile atau penggiling kasar dan kemudian digiling kembali menggunakan mesin powdering sehingga didapat ukuran 300 mesh.

Tidak dilakukan pengayakan

Dikeringkan menggunakan oven lemari selama 1 jam dengan suhu $70^{\circ} \mathrm{C}-80^{\circ} \mathrm{C}$

Dikemas kedalam alumunium foil dengan berat bersih $4 \mathrm{~kg}$
Sumber: Armelle and Mélanie (2010)

Dalam mengendalikan produk dalam proses pencucian, bahan baku yang didapatkan dicuci menggunakan air bersih yang disalurkan oleh PDAM sebanyak tiga tahap pencucian, pada wadah 1 air harus diganti pada lima kali pencucian, wadah 2 harus diganti airnya jika sudah pada 20 kali pencucian, dan untuk wadah 3 tidak perlu dilakukan pergantian/pembaharuan air karena merupakan bilasan terakhir dari tahap pencucian. Pada tahap ini karyawan diwajibkan memakai sarung tangan, penutup kepala, masker untuk menghindari kontainasi.

Peraturan Menteri Perindustrian RI No 75 Tahun 2010 pencucian menggunakan bahan baku harus memenuhi:
1. Air yang digunakan seharusnya memenuhi persyaratan air minum sesuai peraturan perundang-undangan.

2. Air yang digunakan memenuhi persyaratan air bersih sesuai peraturan perundang-undangan.

3. Air, es dan uap panas (steam) harus dijaga agar tidak tercemar bahan lain.

4. Uap panas (steam) yang kontak langsung dengan bahan pangan olahan atau mesin/peralatan harus aman dari bahan-bahan yang berbahaya.

5. Harus dilakukan penanganan dan pemeliharaan pada iir yang digunakan berkali-kali agar tetap aman terhadap pangan yang diolah.

Dengan uraian diatas maka pihak perusahaan memenuhi standar prosedur untuk tahap pencucian bahan baku. Namun prosedur tersebut tidak dijalankan secara 
optimal oleh pihak perusahaan. Pihak perusahaan hanya menjalankan prosedur dengan menggunakan air yang berasal dari PDAM yang disalurkan menggunakan pipa, namun pihak perusahaan belum melakukan pembuktian apakah air tersebut tergolong pada air bersih atau air masih tercemar.

Pada tahap pemisahaan helai daun dari tangkai mutu produk dikendalikan dengan melakukan sortasi pada daun yang berwarna kuning dan masih berwarna pucat. Pada tahap pengeringan daun mutu produk dikendalikan dengan memperhatikan ketebalan bahan yang disebar pada rak yang berukuran $60 \mathrm{~cm} \times 110 \mathrm{~cm}$ yaitu $3 \mathrm{~cm}$. Kemudian digunakan ruang ventilasi dengan menggunakan gas sebagai penghasil energi panas dengan suhu $40-45^{\circ} \mathrm{C}$ selama 16 jam dan dikontrol selamna 5 jam sekali dan untuk menjaga suhu diletakkan termometer ruangan, jika suhu rendah maka suhu akan secara otomatis naik dengan meningkatkan pembakaran sedangkan jika suhu naik/lebih dari suhu maksimum, maka gas tersebut akan mati secara otomatis.

Pada tahap penggiling yang berkaitan dengan tingkat kehalusan tepung daun kelor makan mutu produk dikendalikan dengan dilakukannya dua kali tahap penggilingan pada tahap penggilingan 1, daun kelor yang sudah kering digunakan mesin pencacah dengan ukuran saringan 60-80 mesh, kemudian pada tahap penggilingan 2 , daun yang telah dicacah dimasukkan pada mesin powdering yang menggunakan sistem vakum sehingga dihasilkan produk tepung dengan ukuran 300 mesh. Jika tepung yang dihasilkan masih kasar atau berada dibawah 300 mesh maka daya hisap pada saluran pipa menuju filter akan dikurangi sehingga tepung yang terserap benar-benar halus (300 mesh) penyemburan udara di filter terjadi setiap 10 detik sekali.

Berdasarkan peraturan Menteri Perindustrian Republik Indonesia No 75 Tahun 2010 tentang GMP, menyatakan bahwa setiap proses yang menggunakan mesin, maka mesin tersebut harus menyesuaikan dengan persyaratan antara lain:

1. Jenis produk sesuai

2. Permukaan produk yang dapat kontak langsung dengan bahan pangan olahan, harus halus, tidak berlubang atau bercelah, tidak mengelupas, tidak menyerap air dan tidak berkarat.

3. Bebas dari timbulnya pencemaran terhadap produk oleh jasad renik, bahan logam yang terlepas dari mesin/peralatan, minyak pelumas, bahan bakar, dan bahan-bahan lain yang menimbulkan bahaya.

4. Proses pembersihan mudah dilakukan, didesinfeksi dan pemeliharaan agar dapat mencegah terjadinya pencemaran terhadap produk pangan olahan.

5. Bahan baku merupakan bahan yang awet (tahan lama), tidak mengandung racun, mudah dalam proses pemindahan dan pembongkaran atau pemasangan. Dengan demikian dapat memudahkan dalam proses pembersihan, pemeliharaan, pemantauan, desinfeksi, serta pengendalian hama.

CV. Nurul Jannah telah memenuhi persyatan mesin tersebut, sebab mesin yang digunakan oleh pihak perusahaan terbuat dari bahan stenlis steel yang anti karat. Bahan tersebut juga memiliki permukaan yang halus dantidak berongga, sehingga menghindarkan dari pencemaran. Pada tahap ini karyawan diharuskan menggunakan sarung tangan, masker, dan penutup kepala sebagai alat pelindung diri.

Pada tahap pengeringan tepung yang sudah siap dikemas maka dilakukan pengeringan kembali dengan suhu $70^{\circ} \mathrm{C}$ $80^{\circ} \mathrm{C}$ selama 60 menit, dengan ketebalan 3 $\mathrm{cm}$. Prinsip kerjanya sama seperti pengeringan ruangan yaitu jika suhu terlalu tinggi maka gas akan mati dengan sendiri, sedangkan jika suhu menurun maka gas akan meningkatkan pembakarannya sehingga dihasilkan panas yang tinggi. Namun masalahanya menggunakan suhu yang tinggi akan mengurangi mutu sensori (Prasetyo dkk, 2014) sedangkan 
Hariyadi (2000) dalam Prasetyo dkk (2014) menyatakan bahwa penggunaan suhu tinggi pada proses sterilisasi produk pangan secara berlebihan akan terjadi kerusakan nilai gizi maupun aspek organoleptiknya.

Pada tahap pengepakan yang berhubungan dengan ketahanan produk maka dilakukan pengemasan menggunakan alumunium foil yang mampu menjaga kelmbapan tepung kelor dan juga mampu melindungi dari sinar matahari langsung, kemudian dimasukkan kedalam kardus dan dijilid dan kemudian di treping (diikat dengan emcam tali menggunakan mesin)

Berdasarkan peraturan Menteri Perindustrian Republik Indonesia No 75 Tahun 2010 tentang GMP, kemasan yang digunakan harus memenuhi persyaratan antara lain:

1. Mampu melindungi serta mampu menjaga atau mempertahankan mutu produk pangan olahan dari pengaruh luar, terutama selama masa penyimpanan dalam jangka waktu yang panjang (lama).

2. Terbuat dari bahan yang tidak larut maupun bahan yang dapat melepaskan senyawa-senyawa tertentu yang dapat mengganggu kesehatan atau dapat mempengaruhi/mengubah mutu produk.

3. Tahan terhadap perlakuan selama proses pengolahan,distribusi/pengangkutan, serta kemasan tidak mudah sobek, penyok, maupun pecah selama proses produksi serta tahan terhadap benturan selama proses distribusi.

Tabel 4. Pengendalian Pada Produk Akhir
4. Mampu menjamin keaslian serta keutuhan produk yang dikemas.

5. Mampu memberikan perlindungan berdasarkan aspek desain kemasan terhadap produk, dalam memperkecil kontaminasi, mencegah kerusakan dan memungkinkan kemudahan dalam pemberian label yang baik.

6. Bahan berupa alat pengemas atau berupa gas yang digunakan pada pengemasan produk harus man (tidak beracun), mampu menjaga atau mempertahankan mutu produk serta mampu melindungi produk terhadap pengaruh dari luar.

7. Kemasan yang dapat dipakai kembali seperti botol minuman harus kuat, mudah di bersihkan dan didapat dilakukan desinfeksi bila diperlukan, serta tidak digunakan dalam mengemas produk non-pangan.

8. Bahan yang digunakan sebagai pengemas harus disimpan serta ditangani secara higeinis, terdapat pemisah dari baku dan produk akhir.

CV. Nurul Jannah mengemas produknya menggunakan alumunium foil dan dijaga kebersihannya. Dengan demikian untuk kategori kemasan pihak perusahaan mampu memenuhi persyaratan. Sebab alumunium foil mampu menjaga mutu tepung daun kelor dari kontaminasi dari luar dan melindungi dari cahaya matahari sehingga tepung tetap berwarna hijau.

\section{E. Pengendalian Mutu Produk Akhir}

Pengendalian produk akhir menyangkut proses pada tahap penanganan produk akhir hingga ke tangan konsumen ( tabel 4).

\begin{tabular}{clll}
\hline NO & KEADAAN & \multicolumn{1}{c}{ STANDAR MUTU } & CV. NURU JANNAH \\
\hline 1 & Kehalusan & $\begin{array}{l}\text { Memiliki kehalusan paling } \\
\text { besar200 mesh }\end{array}$ & $\begin{array}{l}\text { Tepung yang dihasilkan } \\
\text { berukuran 300 mesh }\end{array}$ \\
2 & Warna & $\begin{array}{l}\text { Berwarnai hijau dan tidak pucat } \\
\text { (CV. Hikmah) }\end{array}$ & Berwarna hijau \\
3 & Kadar abu & $\begin{array}{l}\text { Memiliki kadar abu paling tinggi } \\
\text { 10-15\% (CV. Hikmah) }\end{array}$ & Kadar abu sebesar 8,34\% \\
4 & Kadar air & $\begin{array}{l}\text { Memiliki kadar air dibawah 7,5\% } \\
\text { (CV. Hikmah) }\end{array}$ & Kadar air sebesar 6,55\% \\
\hline
\end{tabular}

Pada pengemdalian mutu produk tepung daun kelor untuk menghasilkan tepung kelor dengan ukuran partikel 300 mesh perusahaan melakukan du tahap 
penggilingan dengan penggilingan tahap 1 menggunakan mesin pencacah dengan saringan 60-80 mesh. Kemudian pada penggiligan tahap 2 menggunakan mesin powdering dengan sistem vakum. Untuk mengendalikan agar produk tepung memiliki warna hijau, pihak perusahaan melakukan sortasi terhadap bahan baku yang sudah dikeringkan dengan memisahkan daun yang berwarna kekuningan dan yang berwarna hijau, daun yang kekuningan dijual oleh pihak perusahaan sebagai pakan ternak.

Untuk menghasilkan tepung dengan kadar air 6,55\% dan kadar abu 8,34\%, pihak perusahaan melakukan pengeringan daun dengan suhu $40-45^{\circ} \mathrm{C}$ selama $16 \mathrm{jam}$, dan dikontrol selama 5 jam sekali. Selain itu pihak perusahaan juga melakukan uji kandungan gizi dalam kurun waktu 6 bulan sekali. Namun pihak perusahaan belum juga melakukan uji kandungan logam berat dan kandungan mikroorganisme hal tersebut wajib dilakukan seharusnya demi menjamin mutu produk tepung daun kelor yang dihasilkan oleh CV. Nurul Jannah kecamatan Bluto kabupaten Sumenep.

Berdasarkan peraturan Menteri Perindustrian Republik Indonesia No 75 Tahun 2010 tentang GMP, pengendalian produk akhir memerlukan proses penentuan spesifikasi dari produk akhir yang diinginkan dengan tujuan produk yang dihasilkan memiliki keseragaman mutu serta sesuai standar atau persyaratan yang ditetapkan, serta dapat membangun maupun meningkatkan kepercayaan konsumen terhadap produk. Persyaratan yang harus dipenuhi pada produk akhir antara lain:

1. Harus memenuhi persyaratan yang telah ditetapkan oleh otoritas kompeten dan tidak boleh merugikan atau membahayakan kesehatan konsumen.

2. Produk yang belum ditetapkan standar mutunya, dapat ditentukan sendiri oleh perusahaan dengan syarat standar mutu tersebut mengacu pada standar mutu yang berlaku.

3. Harus dilaksanakan pemeriksaan dan pemantauan secara periodik terhadap mutu dan keamanan produk sebelum didistribusikan. pantau secara periodik . Aspek yang diperiksan dan dipantau meliputi organoleptik, mikrobiologi dan atau biologi, fisika dan kimia.

Berdasarkan hasil observasi pihak perusahaan belum mampu mengendalikan produk akhir dengan baik dan benar. Pihak perusahaan mengabaikan keamanan produk dan higeinitas produk sebab masih belum melakukan uji secara perioduk seperti yang telah dijelaskan diatas.

\section{F. Identifikasi Masalah}

1. Diagram Pareto

Prioritas permasalahan berdasarkan pareto diagram sebagaimana gambar 1 .

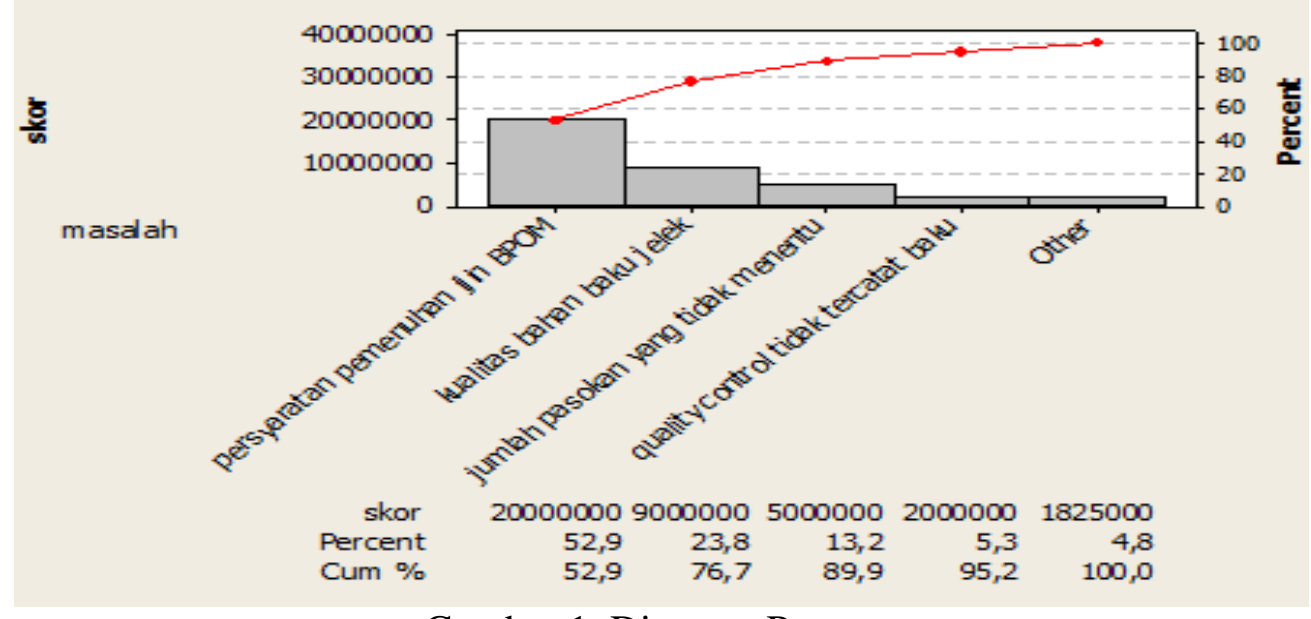

Gambar 1. Diagram Pareto

Berdasarkan gambar 1 dapat dikatakan bahwa masalah utama yang dominan dalam penerapan manajemen mutu ialah persyaratan pemenuhan ijin BPOM dengan persentasi 52,9\%, kemudian dengan kualitas bahan baku jelek sebesar 23,8\%. 
Selanjutnya jumlah pasokan tidak menentu sebesar 13,2\%. Ketiga masalah tersebut harus segera terselesaikan. Pemilihan ketiga masalah tersebut karena memiliki nilai komulatif $89,9 \%$ yang berarti masalah tersebut mempengaruhi dari keseluruhan masalah sebesar 80\%. Maka harus terselesaikan lebih dulu sesuai dengan prinsip Pareto bahwa masalah yang mengakibatkan permasalahan yang besar lebih banyak, lebih mudah diselesaikan.

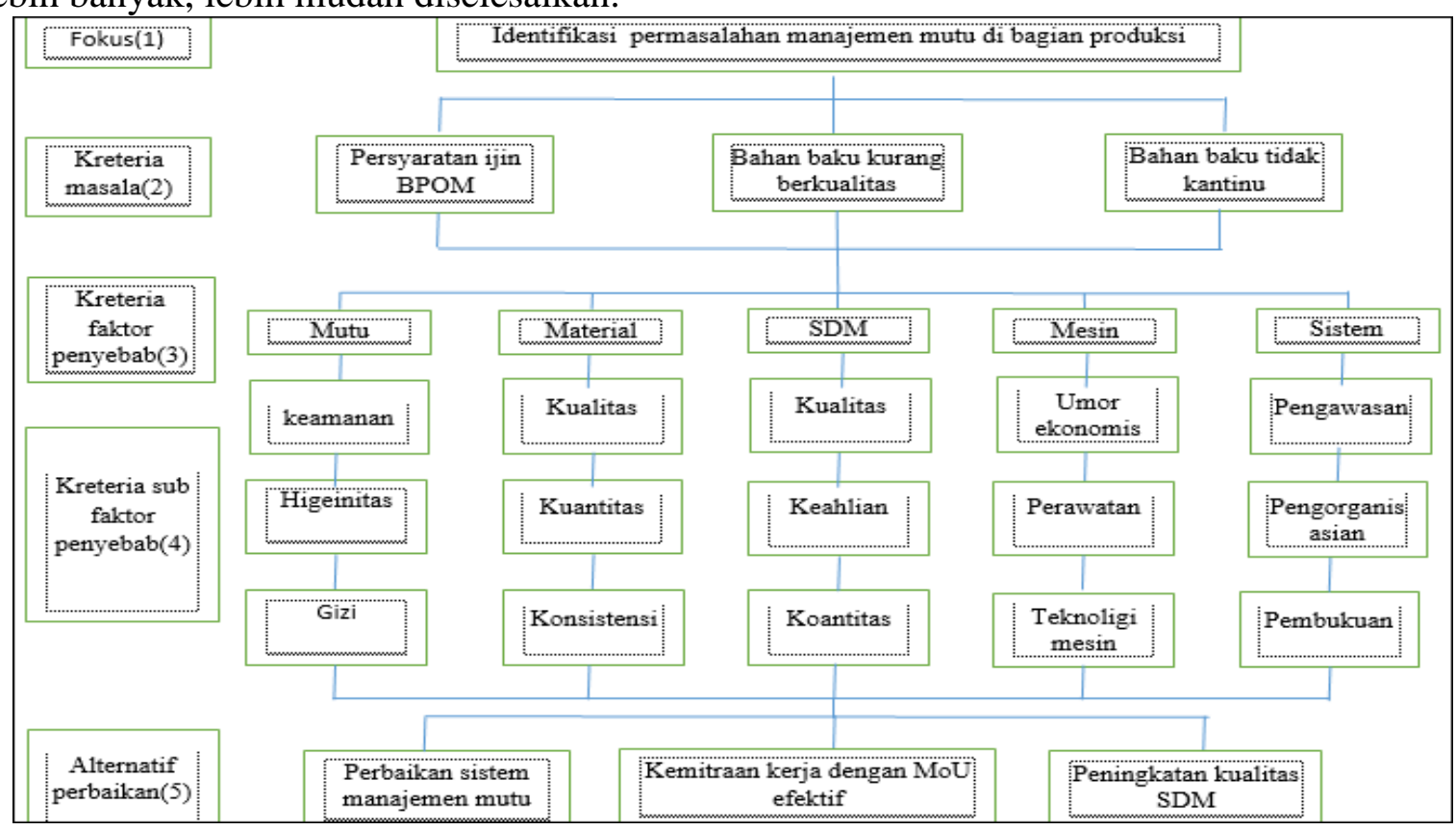

Ganbar 2 Struktur Hirarki Permasalahan Penerapan Manajemen Mutu

Berdasarkan persepsi pihak manajemen selanjutnya dianalisis menggunakan diagram hirarki PHA terhadap masalah penerapan manajemen mutu. asil analisis PHA menggunakan microsoft excel

Tabel 5. Susunan Tingkat Prioritas Kriteria Permasalahan Tingkat 2

dihasilkan susunan prioritas permasalahan manajemen mutu pada tingkat dua. Adapun susunan hirarki permasalahan berdasarkan analisis PHA sebagaimana pada Tabel 5.
Selanjutnya quality control tidak tercatat dengan nilai pengaruh terhadap imbulnya masalah yaitu 5,3\%, serta masalah-masalah lain yang memiliki pengaruh tidak cukup berarti sebesar 4,8\% .

\section{Analitical Hirarki Proses}

Permasalahan yang memiliki keterkaitan dengan penerapan manajemen mutu sebagaimana gambar 2 .
No Tingkat 2 Kriteria Masalah
Bobot PHA
Prioritas

\begin{tabular}{l}
\hline $1 \quad$ Pemenuhan persyaratan ijin BPOM \\
2 Bahan baku kurang berkualitas \\
3 pasokan bahan baku tidak kontinu \\
inconsintency ratio : 0,04
\end{tabular}

Hasil analisis data pada kriteia permasalahan tingkat 2 menunjukkan urutan permasalahan yaitu pemenuhan persyaratan ijin BPOM dengan bobot PHA sebesar 0,78.

Hasil analisis data berdasarkan PHA pada hirarki ditingkatan 3 dan 4

$\begin{array}{ll}0,78 & 1 \\ 0,14 & 2 \\ 0,08 & 3\end{array}$

menunjukkan prioritas faktor penyebab dan subfaktor penyebab masalah penerapan manajemen mutu untuk syarat pemenuhan ijin BPOM sebagaimana gambar 3 output hasil olah data. 


\begin{tabular}{|c|c|c|c|c|c|c|}
\hline $\begin{array}{l}\text { tingket } 7 \\
\text { kniteria } \\
\text { maslah }\end{array}$ & $\begin{array}{l}\text { tiegkat } 3 \\
\text { briteria faktor } \\
\text { Femgrebelb }\end{array}$ & $\begin{array}{l}\text { bobot } \\
\text { BHA }\end{array}$ & prionitas & $\begin{array}{l}\text { tinglcat } 4 \text { kriteria } \\
\text { sub Faktar } \\
\text { perryebeb }\end{array}$ & $\begin{array}{l}\text { bobot } \\
\text { PHA }\end{array}$ & prionitas \\
\hline \multirow{20}{*}{$\begin{array}{l}\text { persyaratan } \\
\text { pememulam } \\
\text { ijin EPOR }\end{array}$} & \multirow{4}{*}{ Mfiath } & \multirow{4}{*}{0.52} & \multirow{4}{*}{1.} & Givi & 0.10 & 3 \\
\hline & & & & Feamanam & 0.67 & II \\
\hline & & & & hiegenitas & 0,23 & 2 \\
\hline & & & & \multicolumn{3}{|c|}{ Inconsintency retio : 0.07} \\
\hline & \multirow{4}{*}{ material } & \multirow{4}{*}{0.24} & \multirow{4}{*}{2} & Bualitas & 0.63 & 1 \\
\hline & & & & knantitas: & 0,11 & 3 \\
\hline & & & & laonsistensi & 0.26 & 2 \\
\hline & & & & \multicolumn{3}{|c|}{ incomsintency retio : $1,0,03$} \\
\hline & \multirow{4}{*}{ SDM } & \multirow{4}{*}{0.14} & \multirow{4}{*}{3} & Mualitas & 0.63 & 1 \\
\hline & & & & keahlian & 0.24 & 2 \\
\hline & & & & kruantitas: & D.os & 3 \\
\hline & & & & inconsintenc & retio: & $0.0 \mathrm{~B}$ \\
\hline & \multirow{4}{*}{ mesin } & \multirow{4}{*}{0.00} & \multirow{4}{*}{4} & wmir Elcosanis & 0.09 & 3 \\
\hline & & & & perawaitan & 0,22 & 2 \\
\hline & & & & teknologęi mesin & D.69 & I \\
\hline & & & & inconsintenc & retio: & 0,05 \\
\hline & \multirow{3}{*}{ sistem } & \multirow{3}{*}{0.04} & \multirow{3}{*}{5} & pengawazen & 0.67 & 1 \\
\hline & & & & pengorgenisasion & 0.10 & 3 \\
\hline & & & & pembulauan & 0.27 & 2 \\
\hline & \multicolumn{3}{|c|}{ inconsintency ratio : 0.06} & inconsintenc & retio: & 0.07 \\
\hline
\end{tabular}

\section{Gambar 3. Output Hasil Analisis PHA}

Faktor penyebab masalah beserta sub faktor pada tingkat hirarki 3 dan 4 didapatkan prioritas pertama faktor penyebab masalah persyaratan pemenuhan ijin BPOM adalah mutu produk $(0,52)$. Berdasarkan analisis PHA faktor penyebab masalah mutu produk yaitu kualitas bahan baku. Kualitas bahan baku yang kurang dengan bobot PHA 0,48.

Berdasarkan analisis lanjut dengan PHA terhadap faktor penyebab kualitas bahan baku kurang yaitu pasokan bahan baku yang tidak kontinu.

Hasil analisis dijabarkan bahwa untuk tingkat 3 dan tingkat 4 pada sub penebab dan sub faktor penyebab masalah pasokan bahan baku tidak kontinu didapatkan prioritas utama dalam sub penyebab dan sub faktor penyebab pasokan bahan baku tidak kontinu adalah material dengan bobot PHA 0,49.

Selanjutnya pengolahan dengan proses hirarki analitik pada susunan hirarki PHA tingkat 5 menghasilkan prioritas alternatif perbaikan untuk permasalahan penerapan manajemen mutu dibagian produksi pada CV. Nurul Jannah yang dapat dilihat dalam Tabel 17.
Tabel 4.10 Prioritas alternatif perbaikan

\begin{tabular}{|l|l|l|l|}
\hline No & \multicolumn{1}{|c|}{$\begin{array}{c}\text { tingkat 5 } \\
\text { Alternatif } \\
\text { Penyelesaian }\end{array}$} & $\begin{array}{c}\text { Bobot } \\
\text { PHA }\end{array}$ & Prioritas \\
\hline 1 & $\begin{array}{l}\text { Perbaikan } \\
\text { sistem } \\
\text { manajemen } \\
\text { mutu }\end{array}$ & 0,65 & 1 \\
\hline 2 & $\begin{array}{l}\text { kemitraan } \\
\text { kerja }\end{array}$ & 0,23 & 2 \\
\hline 3 & $\begin{array}{l}\text { peningkatan } \\
\text { kualitas SDM }\end{array}$ & 0,12 & 3 \\
\hline \multicolumn{3}{|l|}{ Inconsistency ratio: 0,003} \\
\hline
\end{tabular}

(Sumber: Diolah dari data primer, 2018)

Dari tabel diatas mengenai prioritas alternatif perbaikan maka dapat dilihat bahwa prioritas pertama adalah perbaikan sistem manajemen mutu dengan bobot PHA 0,65 . Hal ini menunjukkan bahwasanya pihak perusahan harus melakukan pembenahan terhadap sistem manajemen mutu yang diterapkan saat ini. Pihak CV. Nurul Jannah harus menetapkan standart mutu yang baik, kemudian dilakukan pelaksanaan secara kontinus, kemudian dari pada itu harus juga dilakukan evaluasi mengenai penerapan sistem manajemen mutu dan dilakukan pengembangan sistem untuk mencapai posisi yang optimal.

\section{Kesimpulan}

Penelitian penerapan manajemen mutu di bagian produksi pada industri 
pengolahan daun kelor (studi kasus CV. Nurul Jannah kecamatan Bluto kabupaten sumenep) dapat disimpulkan sebagai berikut:

1. Pelaksanaan penerapan manajemen mutu di bagian produksi pada CV. Nurul Jannah masih belum terlaksana dengan baik. (1) SOP belum dilaksanakan sesuai prosedur, (2) belum melakukan uji kontaminan cemaran logam berat dan uji mikrobiolagi untuk memenuhi persyaratan BPOM, (3) tidak adanya pelatihan karyawan secara terstuktur.

2. Masalah utama dalam penerapan manajemen mutu secara berturut-turut sesuai tingkat kepentingan adalah pemenuhan persyaratan ijin BPOM (52,9\%), kualitas bahan baku yang kurang baik (23,8\%), dan jumlah pasokan bahan baku yang tidak menentu (13,2\%). Akar masalah terhadap kepentingan pemenuhan persyaratan ijin BPOM adalah keamanan pangan $(0,67)$. Kemudian untuk akar masalah dari kualitas bahan baku adalah kualitas bahan baku yang tidak sesuai SOP $(0$, 58). Untuk akar masalah pasokan bahan baku yang tidak kontinu adalah kuantitas bahan baku $(0,68)$. Prioritas alternatif perbaikan yang diperoleh dengan menggunakan analisa PHA disesuaikan dengan kondisi perusahaan secara berurutan yaitu perbaikan sistem manajemen mutu $(0,65)$, kemitraan kerja $(0,23)$, dan peningkatan kinerja SDM $(0,12)$.

\section{DAFTAR PUSTAKA}

Aisyah, Marisa Fajar., Utami, Wiji., Sunardi., Sudarsih. 2017. Kualitas SDM, profesionalisme kerja, dan komitmen sebagai pendukung peningkatan kinerja karyawan PDAM Kabupaten Jember. ejournal ekonomi bisnis dan akuntansi vol IV (1)
Amalia. 2006. Peranan Agroindustri Dalam Pemulihan Perekonomian Indonesia Pasca Krisis Ekonomi. Jakarta. Jurnal Inovasi. 5 (1): 26-27.

Aminah, Syarif., Ramadan, Tezar., Yanis, Muflihani. 2015. Kandungan Nutrisi Dan Sifat Fungsional Tanaman Kelor (Moringa Oleifera). Jakarta. Balai Pengkajian Teknologi Pertanian Jakarta. 5 (2): 35-38.

Arthatiani, Fresty Yulia. 2008. (Skripsi) Penerapan Manajemen Mutu Terpadu Pada PT Maya Food. Pekalongan. Institut Pertanian Bogar.

Armelle and melanie. 2010. Growing And Processing Moringa Leaves. Moringanews/moringa association of ghana. $41-48$

Das, A. K., Rajkumar, V., Verma, A. K.,\& Swarup, D.2012. Moringa Oleifera Leaves Extract: a Natural Antioxidant for Reterding Lipid Peroxidation in Cooked Gooat Meat Patties. International Journal of Food Science and Technology. 47: 585-591.

Gasperz V. 2001. Total Quality Management. Jakarta: PT Gramedia Pustaka Utama.

Hanun, Fitria. 2005. Evaluasi Penerapan Total Quality Management Pada Bagian Produksi PT Mustika Ratu (Skripsi). Jakarta Timur. Universitas Widyatama.

Hardiyanthi, Febby. 2015. Pemanfaatan Aktivitas Antioksidan Ekstrak Daun Kelor (Moringa Oleifera) Dalam Sediaan Hand And Boddy Cream (Skripsi). Jakarta. Universitas Islam Negeri Syarif Hidayatullah.

Mahmood KT, Tahira Mugal, Ikram Ul Haq. 2011. Moringa Oleifera a Natural gift-A Review. Journal of 
Pharmaceuitical Sciences and Research. 2 (11): 775-7781.

Misra, A., Srivastava, S., \& Srivastava, M. 2014. Evaluation of Anti Diarrheal Potential of Moringa Oleifera (Lam) Leaves. Journal of pharmacognosy and phytochemistry.2 (5): 43-46.

Mundir. 2012. Konsep Manajemen Mutu Terpadu (Pengertian, Rasionalitas, Landasan dan Perbedaannya Dengan Manajemen). Jember. Jurnal Universitas Negeri Jember. 2 (1): 4448.

Nasution MN. 2004. Manajemen Mutu Terpadu. Cetakan ke-3. Jakarta: Ghalia Indonesia.

Undang-Undang No 8 Tahun 1999 Tentang Perlindungan Konsumen.

Undang-Undang No 7 Tahun 1996 Tentang Pangan.

Saaty. 2008. Decision Making With The Analytic Hierarchy Proces. Pittsburgh. University of Pittsburgh. Journal Service Sciences. 1 (1): 8587.

Santoso, Stefanie., Johnathan, Billy., Widjadja, Debora C., Jokom, Regina. 2017. Analisa Efektifitas Pelatihan Terhadap Kinerja Karyawan Bumi Surabaya City Resort. Universitas Kristen Petra. Surabaya.

Shah. M. A., Bosco, S. J. D., \& Mir, S. A. 2015. Effect of Moringa Oleifera Leaf Extract on the Physicochemical Properties of Modified Atmosphere Packaged Raw Beef. Food Packaging and Shlf live. 3 :31-38.

SNI No 7387 Tahun 2009 Tentang Batas Maksimum Cemaran Logam Berat Dalamn Pangan.
Sonalia dan Hubeis. 2013. Pengendalian Mutu Pada Proses Produksi di Tiga Usaha Kecil Menengah Tahu Kabupaten Bogor. Bogor. Institut Pertanian Bogor. Jurnal Manajemen Dan Organisasi. 4 (2): 117-19.

Tilong, AD. 2012. Ternyata Kelor Penakluk Diabetes. Jogjakarta. DIVA Press.

Verma, A.R., Vijayakumar, M., Mathela, C.S., ARao, C.V., 2009. In Vitro And In Vivo Antioxidant Properties of Different Fraction of Moringa Oleifera Leaves. Food chem. Toxicol. 47: 2196-2201.

Yameogo, W. C., Bengaly, D. M., Savadogo,A., Nikièma, P. A., Traoré, S. A. 2011. Determination of Chemical Composition And Nutritional Values of Moringa Oleifera Leaves. Pakistan journal of nutrition. 10 (3): 264-268. 